University of South Florida

DIGITAL COMMONS

Digital Commons @ University of

@ UNIVERSITY OF SOUTH FLORIDA

South Florida

$1-1-2012$

\title{
2012 Work Plan USF Tampa
}

USF

Follow this and additional works at: https://digitalcommons.usf.edu/usf_accountability_reports

\section{Scholar Commons Citation}

USF, "2012 Work Plan USF Tampa" (2012). USF Accountability Reports. 33.

https://digitalcommons.usf.edu/usf_accountability_reports/33

This Article is brought to you for free and open access by the USF Archives at Digital Commons @ University of South Florida. It has been accepted for inclusion in USF Accountability Reports by an authorized administrator of Digital Commons @ University of South Florida. For more information, please contact digitalcommons@usf.edu. 


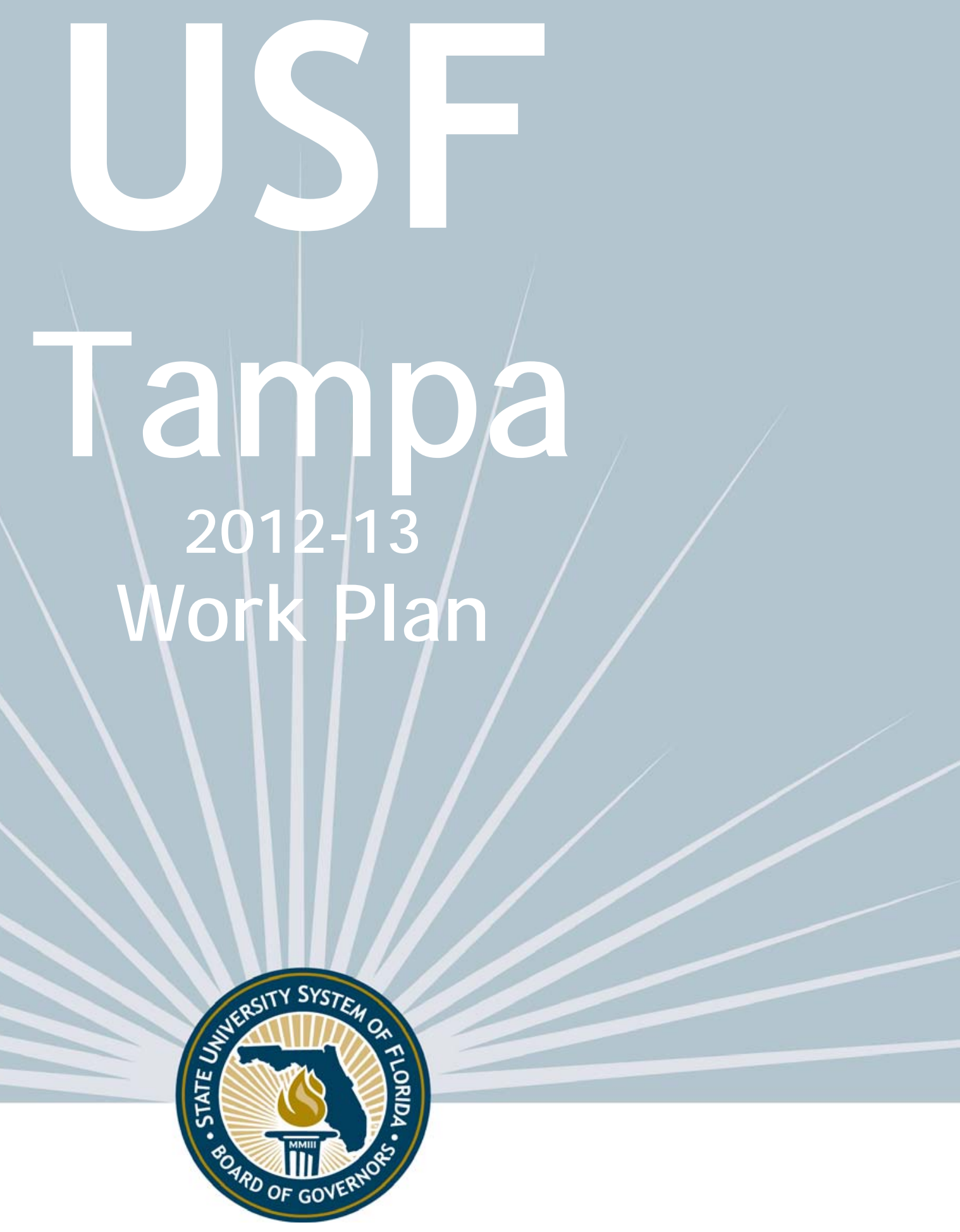

\section{University of South Florida - Tampa}

Work Plan Presentation for 2012-13 Board of Governors Review

Approved by the USF System BOT - June 14, 2012

STATE UNIVERSITY SYSTEM of FLORIDA $\mid$ Board of Governors 


\section{INTRODUCTION}

The State University System of Florida has developed three tools that aid in guiding the System's future.

1) The Board of Governors' new Strategic Plan 2012-2025 is driven by goals and associated metrics that stake out where the System is headed;

2) The Board's Annual Accountability Report provides yearly tracking for how the System is progressing toward its goals;

3) Institutional Work Plans connect the two and create an opportunity for greater dialogue relative to how each institution contributes to the System's overall vision.

These three documents assist the Board with strategic planning and with setting short-, mid- and long-term goals. They also enhance the System's commitment to accountability and driving improvements in three primary areas of focus: 1) academic quality, 2) operational efficiency; and, 3) return on investment.

The Board will use these documents to help advocate for all System institutions and foster even greater coordination with the institutions and their Boards of Trustees.

Once a Work Plan is approved by each institution's respective Boards of Trustees, the Board of Governors will review and consider the plan for potential acceptance of 2012-13 components. Longer-term components will inform future agendas of the Board's Strategic Planning Committee. The Board's acceptance of a work plan does not constitute approval of any particular component, nor does it supersede any necessary approval processes that may be required for each component. 


\section{TABLE OF CONTENTS}

1. STRATEGY
a. Mission Statement
b. Vision Statement
c. Statement of Strategy
d. Strengths and Opportunities
e. Key Initiatives \& Investments

\section{KEY PERFORMANCE INDICATORS}
a. Goals Common to All Universities
b. Goals Specific to Research Universities
c. Institution Specific Goals

3. OPERATIONS
a. Fiscal Information (includes Tuition Differential Fee Request)
b. Enrollment Planning
c. Academic Program Coordination

\section{DEFINITIONS}




\section{MISSION STATEMENT (What is your purpose?)}

The University of South Florida's mission is to deliver competitive undergraduate, graduate and professional programs, to generate knowledge, to foster intellectual development, and to provide cutting-edge learning to ensure student success.

\section{VISION STATEMENT (What do you aspire to?)}

The University of South Florida envisions itself as a premier public research university with state, national and global impact, positioned for membership in the Association of American Universities.

USF is dedicated to: (i) Student success and access through a vibrant, interdisciplinary, and learner-centered environment; (ii) Research and scientific discovery to strengthen the economy, promote civic culture and the arts, and to design and build sustainable communities through the generation, dissemination, and translation of new knowledge across all academic and health-related disciplines; and (iii) Partnerships to build significant and integrated university-community collaborations through technological innovation, and sound scholarly and artistic activities.

\section{STATEMENT OF STRATEGY (How will you get there?)}

Given your mission, vision, strengths and available resources, provide a brief description of your market and your strategy for addressing and leading it.

USF is a RU/VH institution attracting students and faculty of the highest caliber. In moving forward towards AAU eligibility, USF measures its progress by setting clear annual targets for a series of metrics and compares itself to its peer and aspirational peer institutions. USF uses national benchmarks to monitor: Broad measures of academic institutions through the Integrated Postsecondary Education Data System (IPEDS); Its position in the top tier of American research universities through the Carnegie Foundation for the Advancement of Teaching, along with its designation as a Community Engaged University; Performance indices through the Association of American Universities' (AAU); Ranking of research universities through the National Science Foundation (NSF); Ranking of the scope and quality of graduate programs through the National Research Council (NRC); Ranking by the annual report of the Top American Research Universities (TARU); Annual ranking of National Universities US News and World Report's (USNWR); Technology transfers, start-ups and patents through the Association of University Technology Managers (AUTM); Endowment standings through the National Association of Colleges and University Business Officers (NACUBO); Statistics on international education and study abroad through the Institute of International Education/Open Doors (IIE); Moody's credit rating; and Annual giving through Voluntary Support of Education (CAE/VSE). These data are available in several web sites and show trends and comparisons for many of these metrics over the last ten years.

Planning, Performance and Accountability Matrix

PDF of the Planning Metrics Matrix

Performance Dashboard 


\section{STRENGTHS AND OPPORTUNITIES (within 3 years)}

What are your core capabilities, opportunities and challenges for improvement?

USF core capabilities include: Diversity; Excellence in teaching and learning; High impact scholarship, research and creative activities; Success and achievement of its students, faculty, staff and alumni; Shared governance; Collegiality, academic freedom, and professional responsibility; Entrepreneurial spirit, partnerships and innovation; Transparent accountability; Global research, community engagement and public service. The challenge will be to maintain institutional quality, increase educational and research productivity, and enhance revenue under dwindling state resources.

\section{KEY INITIATIVES \& INVESTMENTS (within 3 years)}

Describe your top three key initiatives for the next three years that will drive improvement in Academic Quality, Operational Efficiency, and Return on Investment.

1 Well-educated global citizens through continuing commitment to student success: (a) Provide first-class, comprehensive educational programs and student research opportunities to foster critical thinking and intellectual inquiry; (b) Develop diverse, dynamic global citizens and leaders to strengthen communities, and promote human rights and social justice; (c) Enhance opportunities for students by providing transformational learning that is intellectually, scientifically and technologically sound and produces relevant, applied skills and engaged outcomes including an increased commitment to STEM and health fields; and (d) Educate competitive, highly-skilled students ready to enter the workforce.

To reach this goal, USF will: Recruit high quality students; promote diversity; Infuse global content into existing and new curricula; Increase study abroad and funding/scholarships; Attract global students; Partner with international organizations; Increase student research awards; Increase graduate programs especially in STEM and health-related disciplines; Increase experiential learning opportunities.

2 High-quality research and innovation with global applications to change lives, improve health, and foster sustainable development and positive societal change: (a) Engage in high impact research, scholarship and creative activities that generate new knowledge; (b) Increase research opportunities; (c) Develop strategic interdisciplinary research initiatives that solve critical problems; and (d) Promote community engaged scholarship and creative activities to benefit all members of society.

To reach this goal, USF will: Recruit and retain high quality faculty; build a sustainable research infrastructure; research and grant opportunities; provide training programs that increase the rate of successful funding from national agencies; employ emerging technologies to enhance research and engagement; increase corporate partnerships; promote health and technology innovation; strengthen collaborative partnerships with health, educational, allied science, and engineering entities.

3 A first-class, higher educational institution that drives Tampa Bay region's economic engine: (a) Demonstrate financial security via a sustainable economic base in all business practices; (b) Pursue entrepreneurial endeavors that augment revenue and maximize institutional effectiveness; (c) Establish mutually beneficial partnerships (internal and external) that enhance student access to academic programs, research and employment opportunities; and (d) Provide stewardship of a university that represents the cornerstone of economic and cultural significance for the community. To reach this goal, we will: Define, inform and generate new efficient and effective budget practices; increase understanding and transparency of fiscal affairs and financial longevity; enhance institutional infrastructure by securing mutually beneficial partnerships. market the USF brand via strategic dissemination of information; increase revenue generating patents; establish USF as a community fostering partnerships, employment, k-12 schools, residential opportunities and alumni engagement. 


\section{KEY PERFORMANCE INDICATORS}

The Board of Governors has selected the following Key Performance Indicators, from its 2012-2025 System Strategic Plan and from accountability metrics identified by the Florida Legislature. The Key Performance Indicators emphasize three primary areas of focus: Academic Quality, Operational Efficiency, and Return on Investment. The indicators address common goals across all universities while also providing flexibility to address institution-specific goals from a list of metrics in the 2012-2025 System Strategic Plan.

The Goals Specific to Research Universities apply only to those universities classified by the Carnegie Foundation for the Advancement of Teaching as being a 'Research University'1, which includes Florida A\&M University (by university request), Florida Atlantic University, Florida International University, Florida State University, University of Central Florida, University of Florida, and the University of South Florida.

${ }^{1}$ The Carnegie Foundation for the Advancement of Teaching has developed a well-respected system of categorizing postsecondary institutions that includes consideration of each doctorate-granting university's research activities - for more information see link. 


\section{KEY PERFORMANCE INDICATORS}

\section{Goals Common to All Universities}

\begin{tabular}{cccccc} 
& 5 YEAR & & & & 3 YEAR \\
TREND & $2010-11$ & $2011-12$ & $2012-13$ & GOALS \\
& (05-06 to 10-11) & ACTUAL & ESTIMATES & GOALS & (2014-15) \\
\hline
\end{tabular}

\section{Academic Quality}

\section{National Ranking for University and Programs}

USF will (a) Engage in high impact student success research; (b) Establish partnerships to enhance student access to academic programs, and research; and (c) Educate competitive, highly-skilled (STEM) students ready to enter the workforce. Investment in STEM and ranked programs will continue.

\section{Avg. SAT Score}

Avg. High School GPA (on 4.0 scale)

Professional/Licensure Exam

First-time Pass Rates ${ }^{2}$

Exams Above National/State Benchmark

Exams Below National/State Benchmark

Percent of Undergraduate Seniors Participating in a Research Course

\begin{tabular}{|c|c|c|c|c|}
\hline$-1 \% 1$ & 1676 & 1717 & 1736 & 1740 \\
\hline $5 \%$ & 3.68 & 3.81 & 3.83 & 3.85 \\
\hline $\mathrm{n} / \mathrm{a}$ & 3 & 3 & 4 & 4 \\
\hline $\mathrm{n} / \mathrm{a}$ & 2 & 2 & 1 & 1 \\
\hline
\end{tabular}

\begin{tabular}{|c|c|c|c|c|c|}
\hline SUBTOTAL OF IMPROVING METRICS & 1 & & 2 & 4 & 2 \\
\hline \multicolumn{6}{|l|}{ Operational Efficiency } \\
\hline Freshman Retention Rate & $6 \%$ & $88.3 \%$ & $88.5 \%$ & $89 \%$ & $90 \%$ \\
\hline $\begin{array}{l}\text { FTIC Graduation Rates } \\
\text { In } 4 \text { years (or less) } \\
\text { In } 6 \text { years (or less) }\end{array}$ & $\begin{array}{l}14 \% \\
7 \%\end{array}$ & $\begin{array}{l}34.8 \% \\
50.9 \%\end{array}$ & $\begin{array}{l}35 \% \\
52 \%\end{array}$ & $\begin{array}{l}36 \% \\
52 \%\end{array}$ & $\begin{array}{l}38 \% \\
54 \%\end{array}$ \\
\hline $\begin{array}{l}\text { AA Transfer Graduation Rates } \\
\text { In } 2 \text { years (or less) } \\
\text { In } 4 \text { years (or less) }\end{array}$ & $\begin{array}{l}1 \% \\
5 \%\end{array}$ & $\begin{array}{l}27.9 \% \\
62.1 \%\end{array}$ & $\begin{array}{c}28 \% \\
62.5 \%\end{array}$ & $\begin{array}{l}29 \% \\
63 \%\end{array}$ & $\begin{array}{l}30 \% \\
64 \%\end{array}$ \\
\hline $\begin{array}{l}\text { Percent of Bachelor's Degrees } \\
\text { Without Excess Hours }\end{array}$ & $\mathrm{n} / \mathrm{a}$ & \multicolumn{4}{|c|}{$\begin{array}{l}\text { Board staff is currently updating } \\
\text { the methodology for this metric. }\end{array}$} \\
\hline SUBTOTAL OF IMPROVING METRICS & 5 & & 6 & 5 & 6 \\
\hline \multicolumn{6}{|l|}{ Return on Investment } \\
\hline Bachelor's Degrees Awarded & $36 \%$ & 6,842 & 7,192 & 7,250 & 7,350 \\
\hline Percent of Bachelor's Degrees in STEM & $2 \%$ & $22.7 \%$ & $23.9 \%$ & $24.5 \%$ & $25.8 \%$ \\
\hline Graduate Degrees Awarded & $35 \%$ & 2,715 & 2,845 & 2,900 & 3,000 \\
\hline Percent of Graduate Degrees in STEM & $1 \%$ & $23 \%$ & $22 \%$ & $21 \%$ & $23 \%$ \\
\hline $\begin{array}{l}\text { Percent of Baccalaureate Graduates } \\
\text { Employed in Florida }\end{array}$ & $\mathrm{n} / \mathrm{a}$ & \multicolumn{4}{|c|}{ Data available only at the USF System level } \\
\hline $\begin{array}{l}\text { Percent of Baccalaureate Graduates } \\
\text { Continuing their Education (in FL) }\end{array}$ & $\mathrm{n} / \mathrm{a}$ & \multicolumn{4}{|c|}{ Data available only at the USF System level } \\
\hline Annual Gifts Received (\$M) & $\mathrm{n} / \mathrm{a}$ & \multicolumn{4}{|c|}{ Data available only at the USF System level } \\
\hline Endowment (\$M) & $\mathrm{n} / \mathrm{a}$ & \multicolumn{4}{|c|}{ Data available only at the USF System level } \\
\hline SUBTOTAL OF IMPROVING METRICS & 4 & & 3 & 1 & 4 \\
\hline TOTAL OF IMPROVING METRICS & 10 & & 11 & 10 & 12 \\
\hline
\end{tabular}

Notes: (1) SAT trends are based on 3 year average, (2) Professional licensure pass rates are based on the 2010-11 Annual Accountability Report with data that spans multiple time periods, (3) Percent of graduates employed and continuing their education is based on 2009-10 data from FETPIP. 


\section{KEY PERFORMANCE INDICATORS}

Goals Specific to Research Universities

\begin{tabular}{|c|c|c|c|c|c|}
\hline & $\begin{array}{l}5 \text { YEAR } \\
\text { TREND } \\
\text { (2005-06 } \\
\text { to 2010-11) }\end{array}$ & $\begin{array}{l}2010-11 \\
\text { ACTUAL }\end{array}$ & $\begin{array}{l}2011-12 \\
\text { ESTIMATES }\end{array}$ & $\begin{array}{l}2012-13 \\
\text { GOALS }\end{array}$ & $\begin{array}{l}3 \text { YEAR } \\
\text { GOALS } \\
(2014-15)\end{array}$ \\
\hline \multicolumn{6}{|l|}{ Academic Quality } \\
\hline Faculty Awards & $20 \%$ & 6 est & 10 & 12 & 14 \\
\hline National Academy Members & $50 \%$ & 3 & 3 & 4 & 5 \\
\hline Number of Post-Doctoral Appointees & $64 \%$ & 293 & 310 & 312 & 320 \\
\hline $\begin{array}{l}\text { Number of Science \& Engineering } \\
\text { Disciplines Nationally Ranked in Top } 100 \\
\text { for Research Expenditures (based on } 8 \text { broad } \\
\text { discipline areas, and includes private universities) }\end{array}$ & $\mathrm{n} / \mathrm{a}$ & \multicolumn{4}{|c|}{ Data available only at the USF System level } \\
\hline SUBTOTAL OF IMPROVING METRICS & 3 & & 2 & 3 & 3 \\
\hline \multicolumn{6}{|l|}{ Operational Efficiency } \\
\hline To Be Determined & & \multicolumn{4}{|c|}{$\begin{array}{l}\text { The Board of Governors will work with Universities to } \\
\text { develop metrics associated with Operational Efficiencies }\end{array}$} \\
\hline \multicolumn{6}{|l|}{ Return on Investment } \\
\hline $\begin{array}{l}\text { Total Research Expenditures (\$M) } \\
\text { (includes non-Science \& Engineering disciplines) }\end{array}$ & $\mathrm{n} / \mathrm{a}$ & $\$ 394.9$ & $\$ 414.7$ & $\$ 435.4$ & $\$ 457.2$ \\
\hline $\begin{array}{l}\text { Science \& Engineering Research } \\
\text { Expenditures (\$M) }\end{array}$ & $20 \%$ & $\$ 343.0$ & $\$ 360.2$ & $\$ 378.2$ & $\$ 397.1$ \\
\hline $\begin{array}{l}\text { Percent of Research Expenditures } \\
\text { funded from External Sources }\end{array}$ & $\mathrm{n} / \mathrm{a}$ & $77.76 \%$ & $81.65 \%$ & $85.73 \%$ & $90.02 \%$ \\
\hline Patents Issued & $279 \%$ & 91 & 84 & 67 & 50 \\
\hline Licenses/Options Executed & $71 \%$ & 36 & 37 & 40 & 48 \\
\hline Licensing Income Received (\$M) & $-24 \%$ & $\$ 1.3$ & $\$ 1.3$ & $\$ 2.5$ & $\$ 2.75$ \\
\hline Number of Start-up Companies & $33 \%$ & 8 & 5 & 7 & 8 \\
\hline $\begin{array}{l}\text { Science \& Engineering R\&D Expenditures } \\
\text { in Non-Medical/Health Sciences }\end{array}$ & $24 \%$ & $\$ 136.0$ & $\$ 142.8$ & $\$ 149.9$ & $\$ 157.4$ \\
\hline $\begin{array}{l}\text { National Rank is Higher than Predicted } \\
\text { by the Financial Resources Ranking } \\
\text { (based on U.S. News \& World Report) }\end{array}$ & $\mathrm{n} / \mathrm{a}$ & $181-173$ & $\mathrm{n} / \mathrm{a}$ & $\mathrm{n} / \mathrm{a}$ & $\mathrm{n} / \mathrm{a}$ \\
\hline Research Doctoral Degrees Awarded & $44 \%$ & 267 & 277 & 283 & 340 \\
\hline Professional Doctoral Degrees Awarded & $30 \%$ & 156 & 156 & 158 & 165 \\
\hline SUBTOTAL OF IMPROVING METRICS & $\mathbf{x}$ & & 6 & 10 & 11 \\
\hline TOTAL OF IMPROVING METRICS & $\mathbf{x}$ & & 8 & 13 & 14 \\
\hline
\end{tabular}

Notes: (1) the most recent faculty Awards data is based on 2009-10 data. 


\section{KEY PERFORMANCE INDICATORS}

\section{Institution Specific Goals}

Each university will select three metric goals from the following list of metrics included in the 2012-2025 System Strategic Plan:

\begin{tabular}{l|}
\hline Freshman in Top 10\% of Graduating High School Class \\
\hline Percentage of Eligible Programs with Specialized Accreditation \\
\hline Average Time to Degree for FTICs \\
\hline Bachelor's Degrees Awarded to Minorities \\
\hline Number of Adult (age 25+) Undergraduates Enrolled \\
\hline $\begin{array}{l}\text { Percent of Course Sections Offered via Distance and Blended } \\
\text { Learning }\end{array}$
\end{tabular}
Bachelor's Degrees in Areas of Strategic Emphasis
Graduate Degrees in Areas of Strategic Emphasis
Number of Faculty Designated a Highly Cited Scholar
Seek and/or Maintain Carnegie's Community
Engagement Classification (narrative goal)
Percentage of Students Participating in Identified
Community and Business Engagement Activities
Enrollment in Professional Training and Continuing
Education Courses

\begin{tabular}{lccccc} 
& $\begin{array}{c}\text { 5 YEAR } \\
\text { TREND } \\
\text { (2005-06 to } \\
\text { 2010-11) }\end{array}$ & $\begin{array}{c}\text { 2010-11 } \\
\text { ACTUAL }\end{array}$ & $\begin{array}{c}\text { 2011-12 } \\
\text { ESTIMATES }\end{array}$ & $\begin{array}{c}\mathbf{2 0 1 2 - 1 3} \\
\text { GOALS }\end{array}$ & $\begin{array}{c}\text { 3 YEAR } \\
\text { GOALS } \\
\text { (2014-15) }\end{array}$ \\
\hline $\begin{array}{l}\text { Graduate Degrees in Areas of Strategic } \\
\text { Emphasis }\end{array}$ & $35 \%$ & 1225 & 1250 & 1275 & 1350 \\
\hline $\begin{array}{l}\text { Freshman in Top 10\% of Graduating High } \\
\text { School Class }\end{array}$ & $13 \%$ & $23 \%$ & $24 \%$ & $24.5 \%$ & $25.5 \%$ \\
\hline $\begin{array}{l}\text { Percent of Course Sections Offered via Distance } \\
\text { and Blended Learning }\end{array}$ & $1 \%$ & $11.5 \%$ & $12.5 \%$ & $13.5 \%$ & $14.5 \%$ \\
\hline
\end{tabular}

To further distinguish the university's distinctive mission, the university may choose to provide two additional narrative and metric goals that are based on the university's own strategic plan.

Goal 1. As an RU/VH institution, with a strategic goal of engaging in high impact research, USF will continue to build a sustainable research infrastructure, including total research expenditures as defined by the National Science Foundation.

Total Research Expenditures

n/a

$\$ 394.9 \quad \$ 414.7 \quad \$ 435.4$

$\$ 457.2$

Goal 2. As an RU/VH institution, with a strategic goal of engaging in high impact research, USF will continue to build a sustainable research infrastructure, including federal research expenditures as defined by the National Science Foundation. 


\section{OPERATIONS}




\section{FISCAL INFORMATION}

University Revenues (in Millions of Dollars)

\begin{tabular}{|c|c|c|c|c|c|c|}
\hline & $\begin{array}{l}2007-08 \\
\text { Actual }\end{array}$ & $\begin{array}{l}2008-09 \\
\text { Actual }\end{array}$ & $\begin{array}{l}2009-10 \\
\text { Actual }\end{array}$ & $\begin{array}{l}2010-11 \\
\text { Actual }\end{array}$ & $\begin{array}{l}2011-12 \\
\text { Actual }\end{array}$ & $\begin{array}{c}\text { 2012-13 } \\
\text { Appropriations }\end{array}$ \\
\hline \multicolumn{7}{|c|}{ Education \& General - Main Operations } \\
\hline State Funds & $\$ 253.88$ & $\$ 239.02$ & $\$ 218.00$ & $\$ 217.61$ & $\$ 181.80$ & $\$ 151.52^{\star}$ \\
\hline Tuition & $\$ 93.43$ & $\$ 95.74$ & $\$ 103.95$ & $\$ 118.18$ & $\$ 133.35$ & n/a \\
\hline TOTAL MAIN OPERATIONS & $\$ 347.30$ & $\$ 334.76$ & $\$ 321.95$ & $\$ 335.80$ & $\$ 315.15$ & $\$ 151.52^{*}$ \\
\hline \multicolumn{7}{|c|}{ Education \& General - Health-Science Center / Medical Schools } \\
\hline State Funds & $\$ 66.7$ & $\$ 62.8$ & $\$ 66.6$ & $\$ 68.3$ & $\$ 64.8$ & $\$ 65.2^{*}$ \\
\hline Tuition & $\$ 22.6$ & $\$ 26.3$ & $\$ 30.0$ & $\$ 32.9$ & $\$ 34.5$ & $\mathrm{n} / \mathrm{a}$ \\
\hline TOTAL HSC & $\$ 89.3$ & $\$ 89.1$ & $\$ 96.6$ & $\$ 101.2$ & $\$ 99.3$ & $\$ 65.2^{*}$ \\
\hline $\begin{array}{l}\text { EDUCATION \& GENERAL } \\
\text { TOTAL REVENUES }\end{array}$ & $\$ 436.60$ & $\$ 423.86$ & $\$ 418.55$ & $\$ 437.00$ & $\$ 414.45$ & $\$ 216.72^{*}$ \\
\hline
\end{tabular}

Note: State funds include General Revenue funds, Lottery funds, Federal Stimulus funds, and Phosphate Research funds (for Polytechnic) appropriated by the Florida Legislature (as reported in the Annual Accountability Report). Actual tuition includes base tuition and tuition differential fee revenues for resident and non-resident undergraduate and graduate students net of waivers (as reported in the Annual Accountability Report). Actual tuition revenues are not yet available for the 2012-13 year.

*Per SB1994, the 2012-13 appropriations state funds amount includes the \$10M funding amount and \$6M for Pharmacy

\section{OTHER BUDGET ENTITIES}

\section{Auxiliary Enterprises}

Resources associated with auxiliary units that are self-supporting through fees, payments and charges. Examples include housing, food services, bookstores, parking services, health centers.
Revenues
Data are reported at the USF System level

\section{Contracts \& Grants}

Resources received from federal, state or private sources for the purposes of conducting research and public service activities.
Revenues
Data are reported at the USF System level

\section{Local Funds}

Resources associated with student activity (supported by the student activity fee), student financial aid, concessions, intercollegiate athletics, technology fee, green fee, and student life \& services fee.

\section{Revenues}

Data are reported at the USF System level

\section{Faculty Practice Plans}

Revenues/receipts are funds generated from faculty practice plan activities.
Revenues
OTHER BUDGET ENTITY
TOTAL REVENUES
Data are reported at the USF System level
UNIVERSITY REVENUES
GRAND TOTAL
Data are reported at the USF System level
Data are reported at the USF System level 


\section{FISCAL INFORMATION (continued)}

Undergraduate Resident Tuition Summary (for 30 credit hours)

\begin{tabular}{lccccc} 
& $\begin{array}{c}\text { FY 2010-11 } \\
\text { ACTUAL }\end{array}$ & $\begin{array}{c}\text { FY 2011-12 } \\
\text { ACTUAL }\end{array}$ & $\begin{array}{c}\text { FY 2012-13 } \\
\text { REQUEST }\end{array}$ & $\begin{array}{c}\text { FY 2013-14 } \\
\text { PLANNED }\end{array}$ & $\begin{array}{c}\text { FY 2014-15 } \\
\text { PLANNED }\end{array}$ \\
\hline Base Tuition & $\$ 2,870$ & $\$ 3,100$ & $\$ 3,100$ & $\$ 3,100$ & $\$ 3,100$ \\
\hline Tuition Differential Fee & $\$ 660$ & $\$ 960$ & $\$ 1,406$ & $\$ 2,082$ & $\$ 2,859$ \\
\hline Percent Increase & $15 \%$ & $15 \%$ & $11 \%$ & $15 \%$ & $15 \%$ \\
\hline Required Fees $^{1}$ & $\$ 1,668$ & $\$ 1,746$ & $\$ 1,828$ & $\$ 1,828$ & $\$ 1,828$ \\
\hline TOTAL TUITION AND FEES & $\$ 5,198$ & $\$ 5,806$ & $\$ 6,335$ & $\$ 7,010$ & $\$ 7,787$
\end{tabular}

Note 1: For more information regarding required fees see list of per credit hour fees and block fees on page 16.

\section{Student Debt Summary}

\begin{tabular}{|c|c|c|c|c|c|}
\hline 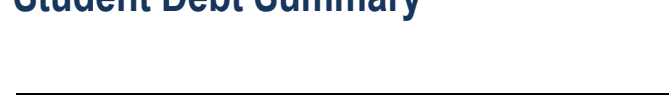 & $\begin{array}{r}2007-08 \\
\text { ACTUAL }\end{array}$ & $\begin{array}{r}2008-09 \\
\text { ACTUAL }\end{array}$ & $\begin{array}{r}2009-10 \\
\text { ACTUAL }\end{array}$ & $\begin{array}{r}2010-11 \\
\text { ACTUAL }\end{array}$ & $\begin{array}{c}\text { 2011-12 } \\
\text { ESTIMATE }\end{array}$ \\
\hline Percent of Bachelor's Recipients with Debt & $53 \%$ & $52 \%$ & $52 \%$ & $53 \%$ & $53 \%$ \\
\hline $\begin{array}{l}\text { Average Amount of Debt } \\
\text { for Bachelor's who have graduated with debt }\end{array}$ & $\$ 18,517$ & $\$ 19,963$ & $\$ 21,811$ & $\$ 21,784$ & $\$ 21,784$ \\
\hline Student Loan Cohort Default Rate (2nd Year) & $4.9 \%$ & $6.3 \%$ & $7.0 \%$ & $\mathrm{n} / \mathrm{a}$ & $\mathrm{n} / \mathrm{a}$ \\
\hline Student Loan Cohort Default Rate (3rd Year) & $x x \%$ & $x \times \%$ & $10.1 \%$ & $\mathrm{n} / \mathrm{a}$ & $\mathrm{n} / \mathrm{a}$ \\
\hline
\end{tabular}

Cost of Attendance (for Full-Time Undergraduate Florida Residents in the Fall and Spring of 2011-12)

\begin{tabular}{ccccccc} 
& $\begin{array}{c}\text { TUITION } \\
\& \text { FEES }\end{array}$ & $\begin{array}{c}\text { BOOKS } \& \\
\text { SUPPLIES }\end{array}$ & $\begin{array}{c}\text { ROOM } \\
\text { \& BOARD }\end{array}$ & TRANSPORTATION & $\begin{array}{c}\text { OTHER } \\
\text { EXPENSES }\end{array}$ & TOTAL \\
\hline ON-CAMPUS & $\$ 5,800$ & $\$ 1,500$ & $\$ 9,190$ & $\$ 1,600$ & $\$ 2,500$ & $\$ 20,590$ \\
\hline AT HOME & $\$ 5,800$ & $\$ 1,500$ & $\$ 4,590$ & $\$ 1,600$ & $\$ 2,500$ & $\$ 15,990$ \\
\hline
\end{tabular}

Estimated Net Cost by Family Income (for Full-Time Undergraduate Florida Residents in the Fall and Spring of 2011-12)

\begin{tabular}{|c|c|c|c|c|c|c|}
\hline \multirow{2}{*}{$\begin{array}{l}\text { FAMILY } \\
\text { INCOME } \\
\text { GROUPS }\end{array}$} & \multicolumn{2}{|c|}{$\begin{array}{l}\text { FULL-TIME RESIDENT } \\
\text { UNDERGRADUATES }\end{array}$} & \multirow{2}{*}{$\begin{array}{c}\text { AVG. NET } \\
\text { COST OF } \\
\text { ATTENDANCE }\end{array}$} & \multirow{2}{*}{$\begin{array}{c}\text { AVG. NET } \\
\text { TUITION } \\
\& \text { FEES } \\
\end{array}$} & \multirow{2}{*}{$\begin{array}{l}\text { AVERAGE } \\
\text { GIFT AID } \\
\text { AMOUNT }\end{array}$} & \multirow{2}{*}{$\begin{array}{l}\text { AVERAGE } \\
\text { LOAN } \\
\text { AMOUNT }\end{array}$} \\
\hline & HEADCOUNT & PERCENT & & & & \\
\hline Below $\$ 40,000$ & 6,650 & $38 \%$ & $\$ 11,495$ & $-\$ 3,009$ & $\$ 8,429$ & $\$ 4,219$ \\
\hline$\$ 40,000-\$ 59,999$ & 2,243 & $13 \%$ & $\$ 13,822$ & $-\$ 419$ & $\$ 5,909$ & $\$ 4,106$ \\
\hline$\$ 60,000-\$ 79,999$ & 1,774 & $10 \%$ & $\$ 15,771$ & $\$ 1,740$ & $\$ 3,801$ & $\$ 4,323$ \\
\hline$\$ 80,000-\$ 99,999$ & 1,477 & $8 \%$ & $\$ 16,632$ & $\$ 2,633$ & $\$ 2,911$ & $\$ 4,094$ \\
\hline$\$ 100,000$ Above & 4,301 & $24 \%$ & $\$ 16,617$ & $\$ 2,590$ & $\$ 2,977$ & $\$ 2,913$ \\
\hline Missing & 1,156 & $7 \%$ & $\$ 17,853$ & $\$ 4,656$ & $\$ 815$ & $\$ 219$ \\
\hline TOTAL & 17,601 & $100 \%$ & $\$ 14,323$ & $\$ 145$ & $\$ 5,346$ & $\$ 3,623$ \\
\hline
\end{tabular}

Notes: This data only represents Fall and Spring financial aid data, and is accurate as of March 31, 2012. Please note that small changes to Spring 2012 awards are possible before the data is finalized. Family Income Groups are based on the Total Family Income (including untaxed income) as reported on student FAFSA records. Full-time Students is a headcount based on at least 24 credit hours during Fall and Spring terms. Average Gift Aid includes all grants and scholarships from Federal, State, University and other private sources administered by the Financial Aid Office. Student waivers are also included in the Gift Aid amount. Gift Aid does not include the parental contribution towards EFC. Net Cost of Attendance is the actual average of the total Costs of Attendance (which will vary by income group due to the diversity of students living on- \& off- campus) minus the average Gift Aid amount. Net Tuition \& Fees is the actual average of the total costs of tuition and fees (which will vary by income group due to the amount of credit hours students are enrolled) minus the average Gift Aid amount (see page 16 for list of fees that are included). Average Loan Amount includes Federal (Perkins, Stafford, Ford Direct, and PLUS loans) and all private loans. The bottom-line Average represents the average of all full-time undergraduate Florida residents. 


\section{FISCAL INFORMATION (continued) TUITION DIFFERENTIAL FEE REQUEST FOR 2012-13}

\begin{tabular}{|c|c|}
\hline \multicolumn{2}{|c|}{ Effective Date } \\
\hline University Board of Trustees Approval Date: & June 14, 2012 \\
\hline Implementation Date (month/year): & August 2012 \\
\hline \multicolumn{2}{|c|}{ Campus or Center Location } \\
\hline $\begin{array}{l}\text { Campus or Center Location to which the Tuition Differential fee } \\
\text { will apply (If the entire university, indicate as such): }\end{array}$ & Entire university \\
\hline \multicolumn{2}{|c|}{ Undergraduate Course(s) } \\
\hline $\begin{array}{l}\text { Course(s). (If the tuition differential fee applies to all university } \\
\text { undergraduate courses, indicate as such. If not, also provide a } \\
\text { rationale for the differentiation among courses): }\end{array}$ & All university undergraduate courses \\
\hline \multicolumn{2}{|c|}{ Current and Proposed Increase in the Tuition Differential Fee } \\
\hline Current Undergraduate Tuition Differential per credit hour: & $\$ 32.00$ \\
\hline $\begin{array}{l}\text { Percentage tuition differential fee increase (calculated as a } \\
\text { percentage of the sum of base tuition plus tuition differential): }\end{array}$ & $11 \%$ \\
\hline \$ Increase in tuition differential per credit hour: & $\$ 14.88$ \\
\hline \$ Increase in tuition differential for 30 credit hours: & $\$ 446.40$ \\
\hline \multicolumn{2}{|c|}{ Projected Differential Revenue Generated } \\
\hline $\begin{array}{l}\text { Incremental differential fee revenue generated in 2012-13 } \\
\text { (projected) : }\end{array}$ & $\$ 11,853,192$ \\
\hline Total differential fee revenue generated in 2012-13 (projected): & $\$ 32,357,268$ \\
\hline
\end{tabular}

Cost-efficient utilization of instructional technology and innovation , along with investments in faculty and professional staff to enhance timely college completion rates, attainment and career placement through activities such as:

- Need-Based Financial Aid (at 40\%): Expand access for students; and accelerated path to graduation. Provide much needed financial support for talented students with limited income as Pell grant funding continues to shrink. More students supported with financial aid scholarships and reduced loan indebtedness.

- Expanding the High Skilled Workforce and Assuring Job Placement, especially in STEM: Expanded STEM and IT programs and degrees awarded; Strengthened relationships with business and industry; Increased number of co-op partnerships; Expanded professional support for job placement through USF's Career Center/Job Hub.

- Academic Advising and Veterans' Support: Enhanced academic advising through technology, focus on goal setting, time-to-degree, improved graduation rates, reducing excess hours, and expanding USF's Veterans' Success program. Improved tracking of students and graduates.

- Financial Counseling and Debt Reduction: Financial impact of the increasing costs of higher education mitigated through focused and proactive financial counseling and debt reduction strategies. Reduced amount of student debt. Reduced number and percentage of students with debt.

\section{Describe the Impact to the Institution if Tuition Differential is Not Approved}

Significant risk and negative impact on progress toward BOG/SUS and BOT/USF strategic goals. USF System efforts to move away from the traditional delivery model will be significantly impaired or delayed, potentially resulting in stagnant or declining graduation rates and a reduced ability to meet the workforce demands of the state. The loss of potential needbased financial aid (40\%) will further reduce student access, retention and graduation rates while likely increasing student indebtedness. USF's commitment to investing in (60\%) enhanced instruction and learning (particularly in STEM), serving returning veterans, reducing excess hours and student debt, and job placement for graduates will be diminished or, at best, delayed. 


\section{Request to Modify or Waive Tuition Differential Uses}

(this section is applicable only if HB 7135 is signed by the Governor and the university wishes to request a change to the $70 \%$ I $30 \%$ intended uses criteria identified in Regulation 7.001(14))

The University of South Florida System is requesting permission to change the intended use criteria for tuition differential uses, identified in Regulation 7.001(14), for academic year 2012-2013 from 70\%/30\% to 60\%/40\%. The proportion of Pell eligible students at USF now exceeds $40 \%$, and with declining federal aid, the institution believes that this is a worthwhile investment to ensure timely completion of degrees and reduced student indebtedness.

*2012-13 includes students from USF in Lakeland 


\section{FISCAL INFORMATION (continued) TUITION DIFFERENTIAL SUPPLEMENTAL INFORMATION}

Provide the following information for the 2011-12 academic year.

\begin{tabular}{|c|c|}
\hline $\begin{array}{l}\text { 2011-2012 - 70\% Initiatives (list the initiatives provided in } \\
\text { the 2011-12 tuition differential request) }\end{array}$ & University Update on Each Initiative \\
\hline Improve Baccalaureate retention and graduation & 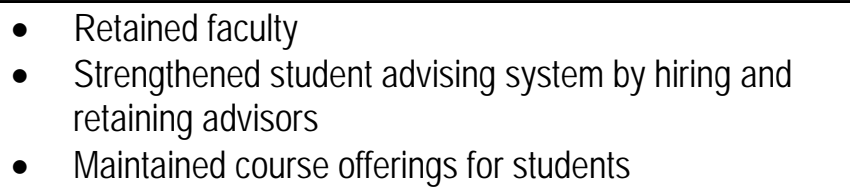 \\
\hline \multicolumn{2}{|c|}{ Additional Detail, where applicable: } \\
\hline $\begin{array}{l}\text { Total Number of Faculty Hired or Retained (funded by tuition } \\
\text { differential): }\end{array}$ & 46 faculty equivalents hired or retained \\
\hline $\begin{array}{l}\text { Total Number of Advisors Hired or Retained (funded by } \\
\text { tuition differential): }\end{array}$ & 40 advisors hired or retained \\
\hline $\begin{array}{l}\text { Total Number of Course Sections Added or Saved (funded } \\
\text { by tuition differential): }\end{array}$ & 184 sections saved \\
\hline $\begin{array}{l}\text { 2011-2012 - 30\% Initiatives (list the initiatives provided in } \\
\text { the 2011-12 tuition differential request) }\end{array}$ & University Update on Each Initiative \\
\hline $\begin{array}{l}\text { Increase the number of students who are awarded grants } \\
\text { funded by the tuition differential. }\end{array}$ & $\begin{array}{l}\text { The number of students supported increased to 6,116 (an } \\
\text { increase of 2,860 students, or } 87.8 \% \text { ) }\end{array}$ \\
\hline $\begin{array}{l}\text { Increase the average amount of awards in order to partially } \\
\text { off-set tuition increases for needy students. }\end{array}$ & $\begin{array}{l}\text { The average award increased by } \$ 137 \text {, which represents an } \\
\text { increase of } 11.5 \% \text {. }\end{array}$ \\
\hline \multicolumn{2}{|c|}{ Additional Information (estimates as of April 30, 2012): } \\
\hline $\begin{array}{l}\text { Unduplicated Count of Students Receiving at least one } \\
\text { Tuition Differential-Funded Award: }\end{array}$ & 6,116 \\
\hline $\begin{array}{l}\text { \$ Mean (per student receiving an award) of Tuition } \\
\text { Differential-Funded Awards: }\end{array}$ & 1,324 \\
\hline $\begin{array}{l}\text { \$ Minimum (per student receiving an award) of Tuition } \\
\text { Differential-Funded Awards: }\end{array}$ & 100 \\
\hline $\begin{array}{l}\text { \$ Maximum (per student receiving an award) of Tuition } \\
\text { Differential-Funded Awards: }\end{array}$ & 2,500 \\
\hline
\end{tabular}




\section{FISCAL INFORMATION (continued) TUITION DIFFERENTIAL COLLECTIONS, EXPENDITURES, \& AVAILABLE BALANCES - FISCAL YEAR 2011-12 AND 2012-13}

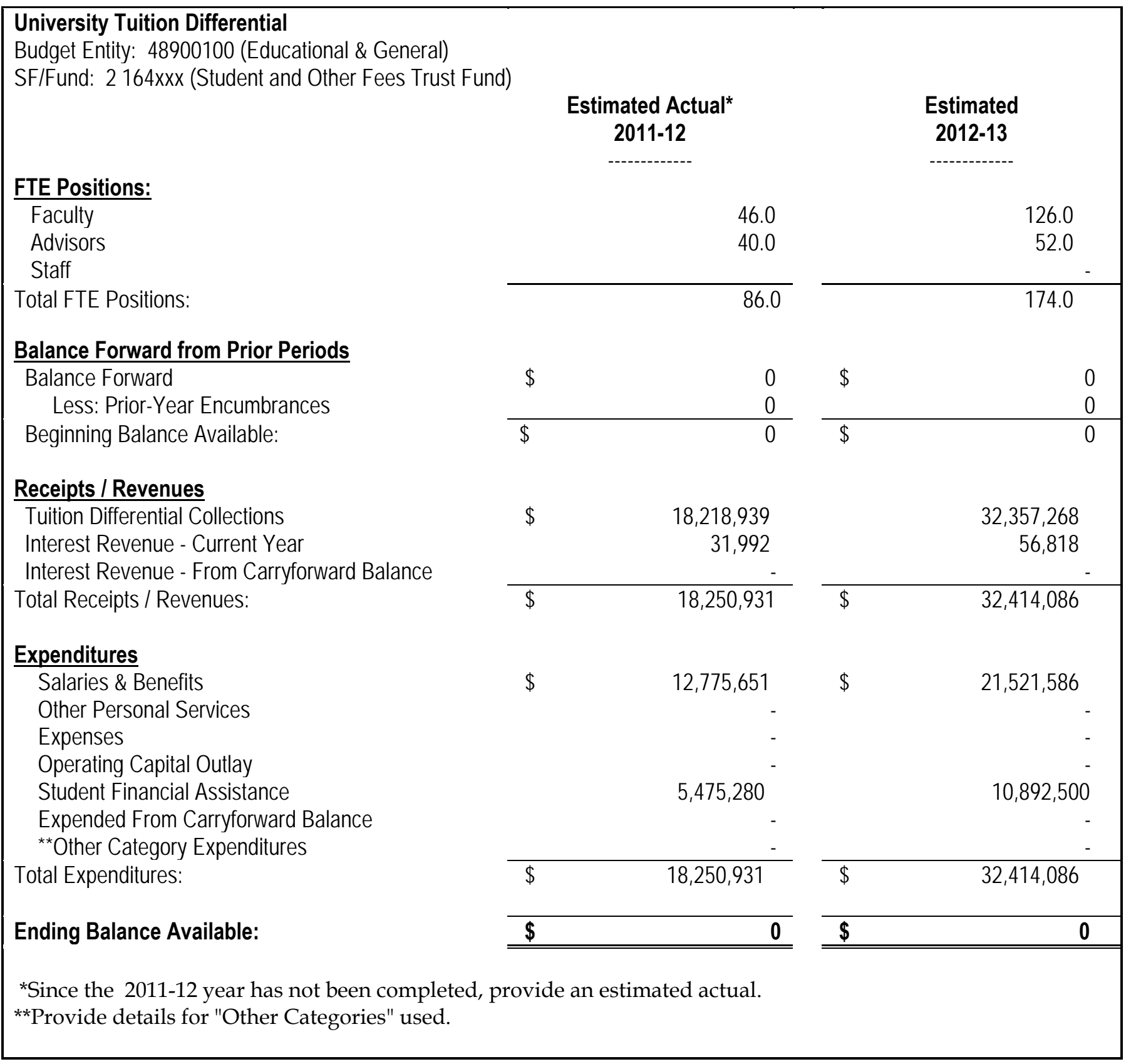

*2012-13 includes students from USF in Lakeland 


\section{FISCAL INFORMATION (continued) UNIVERSITY TUITION, FEES AND HOUSING PROJ ECTIONS}

University of South Forida- Main Campus

\begin{tabular}{|c|c|c|c|c|c|c|c|}
\hline \multirow[t]{2}{*}{ Undergraduate Students } & \multicolumn{3}{|c|}{$\longrightarrow$ Actual— } & \multicolumn{4}{|c|}{ Projected- } \\
\hline & $2009-10$ & 2010-11 & 2011-12 & 2012-13 & 2013-14 & $2014-15$ & 2015-16 \\
\hline \multicolumn{8}{|l|}{ Tuition: } \\
\hline Base Tution- (0\%projected legislative & $\$ 88.59$ & $\$ 95.67$ & $\$ 103.32$ & $\$ 103.32$ & $\$ 103.32$ & $\$ 103.32$ & $\$ 103.32$ \\
\hline Tuition Differential (nomore than 15\%) & $\$ 13.74$ & $\$ 2200$ & $\$ 32.00$ & $\$ 46.88$ & $\$ 69.41$ & $\$ 95.31$ & $\$ 125.10$ \\
\hline Total Base Tuitionand Differential & $\$ 10233$ & $\$ 117.67$ & $\$ 135.32$ & $\$ 150.21$ & $\$ 17273$ & $\$ 198.63$ & $\$ 228.42$ \\
\hline \%Change & & $15.0 \%$ & $15.0 \%$ & $110 \%$ & $15.0 \%$ & $15.0 \%$ & $15.0 \%$ \\
\hline \multicolumn{8}{|l|}{ Fees (per credit hour): } \\
\hline Studert Financial Aid ${ }^{1}$ & $\$ 4.42$ & $\$ 4.78$ & $\$ 5.16$ & $\$ 5.16$ & $\$ 5.16$ & $\$ 5.16$ & $\$ 5.16$ \\
\hline Building/Capital Improvemert $^{2}$ & $\$ 4.76$ & $\$ 4.76$ & $\$ 4.76$ & $\$ 6.76$ & $\$ 6.76$ & $\$ 6.76$ & $\$ 6.76$ \\
\hline Activity \& Senvice & $\$ 9.31$ & $\$ 1128$ & $\$ 1128$ & $\$ 1171$ & $\$ 1171$ & $\$ 1171$ & $\$ 1171$ \\
\hline Health & $\$ 8.60$ & $\$ 9.30$ & $\$ 9.73$ & $\$ 9.73$ & $\$ 9.73$ & $\$ 9.73$ & $\$ 9.73$ \\
\hline Athletic & $\$ 1176$ & $\$ 13.73$ & $\$ 14.15$ & $\$ 14.46$ & $\$ 14.46$ & $\$ 14.46$ & $\$ 14.46$ \\
\hline TransportationAccess & $\$ 3.00$ & $\$ 3.00$ & $\$ 3.00$ & $\$ 3.00$ & $\$ 3.00$ & $\$ 3.00$ & $\$ 3.00$ \\
\hline Tedmology 1 & $\$ 4.42$ & $\$ 4.78$ & $\$ 5.16$ & $\$ 5.16$ & $\$ 5.16$ & $\$ 5.16$ & $\$ 5.16$ \\
\hline Other (iist): Narshall Center & $\$ 150$ & $\$ 1.50$ & $\$ 150$ & $\$ 150$ & $\$ 1.50$ & $\$ 1.50$ & $\$ 1.50$ \\
\hline Sudert GeenEnergy & & & $\$ 100$ & $\$ 100$ & $\$ 1.00$ & $\$ 1.00$ & $\$ 100$ \\
\hline \multicolumn{8}{|l|}{ Academic Enichment and Opportunity } \\
\hline Subtotal (credithour fees) & $\$ 47.77$ & $\$ 53.13$ & $\$ 55.74$ & $\$ 58.48$ & $\$ 58.48$ & $\$ 58.48$ & $\$ 58.48$ \\
\hline Total Tuition and Fees per credit ho & $\$ 150.10$ & $\$ 170.80$ & $\$ 19106$ & $\$ 208.69$ & $\$ 23121$ & $\$ 257.11$ & $\$ 286.90$ \\
\hline \%Change & & $13.8 \%$ & $119 \%$ & $9.2 \%$ & $10.8 \%$ & $11.2 \%$ & $116 \%$ \\
\hline \multicolumn{8}{|l|}{ Fees(block per tem): } \\
\hline Adivity\&Senvice & $\$ 7.00$ & $\$ 7.00$ & $\$ 7.00$ & $\$ 7.00$ & $\$ 7.00$ & $\$ 7.00$ & $\$ 7.00$ \\
\hline \multicolumn{8}{|l|}{ Health } \\
\hline Athletic & $\$ 10.00$ & $\$ 10.00$ & $\$ 10.00$ & $\$ 10.00$ & $\$ 10.00$ & $\$ 10.00$ & $\$ 10.00$ \\
\hline \multicolumn{8}{|l|}{ TransportationAccess } \\
\hline Oher (ist): Nershall Certer & $\$ 20.00$ & $\$ 20.00$ & $\$ 20.00$ & $\$ 20.00$ & $\$ 20.00$ & $\$ 20.00$ & $\$ 20.00$ \\
\hline Total BlockFees per term & $\$ 37.00$ & $\$ 37.00$ & $\$ 37.00$ & $\$ 37.00$ & $\$ 37.00$ & $\$ 37.00$ & $\$ 37.00$ \\
\hline \begin{tabular}{|c|} 
\%Change \\
\end{tabular} & & $0.0 \%$ & $0.0 \%$ & $0.0 \%$ & $0.0 \%$ & $0.0 \%$ & $0.0 \%$ \\
\hline Total Tuition for 30 Credit Hours & $\$ 3,069.90$ & $\$ 3,530.10$ & $\$ 4,059.60$ & $\$ 4,506.30$ & $\$ 5,181.90$ & $\$ 5,958.90$ & $\$ 6,85260$ \\
\hline Total Fees for 30 Credit Hours & $\$ 1,507.10$ & $\$ 1,667.90$ & $\$ 1,746.20$ & $\$ 1,82840$ & $\$ 1,82840$ & $\$ 1,82840$ & $\$ 1,828,40$ \\
\hline Total Tuition and Fees for 30 Credit & $\$ 4,577.00$ & $\$ 5,198,00$ & $\$ 5,805,80$ & $\$ 6,334,70$ & $\$ 7,010.30$ & $\$ 7,787.30$ & $\$ 8,681,00$ \\
\hline \$Change & & $\$ 62100$ & $\$ 607.80$ & $\$ 528.90$ & $\$ 675.60$ & $\$ 777.00$ & $\$ 893.70$ \\
\hline \%Change & & $13.6 \%$ & $117 \%$ & $9.1 \%$ & $10.7 \%$ & $111 \%$ & $115 \%$ \\
\hline \multicolumn{8}{|l|}{ Out-of-StateFees } \\
\hline Ot-of-State Undergraduate Fee & $\$ 343.16$ & $\$ 343.16$ & $\$ 29168$ & $\$ 315.00$ & $\$ 315.00$ & $\$ 315.00$ & $\$ 315.00$ \\
\hline Percentage change & & & $-15.0 \%$ & & & & \\
\hline Ot-of-State Undergraduate Studert $F$ & $\$ 17.15$ & $\$ 17.15$ & $\$ 14.58$ & $\$ 15.75$ & $\$ 15.75$ & $\$ 15.75$ & $\$ 15.75$ \\
\hline Total per credit hour & $\$ 360.31$ & $\$ 360.31$ & $\$ 306.26$ & $\$ 330.75$ & $\$ 330.75$ & $\$ 330.75$ & $\$ 330.75$ \\
\hline \%Change & & $0 \%$ & $0 \%$ & $8 \%$ & $0 \%$ & $0 \%$ & $0 \%$ \\
\hline Total Tuition for 30 Credit Hours & $\$ 3,069.90$ & $\$ 3,530.10$ & $\$ 4,059.60$ & $\$ 4,506.30$ & $\$ 5,181.90$ & $\$ 5,958.90$ & $\$ 6,85260$ \\
\hline Total Fees for 30 Credit Hours & $\$ 12,316,40$ & $\$ 12,477.20$ & $\$ 10,934,00$ & $\$ 11,750.90$ & $\$ 11,750.90$ & $\$ 11,750.90$ & $\$ 11,750.90$ \\
\hline Total Tuition and Fees for 30 Credit & $\$ 15,386.30^{\prime}$ & $\$ 16,007.30$ & $\$ 14,993.60$ & $\$ 16,257.20$ & $\$ 16,93280$ & $\$ 17,709.80$ & $\$ 18,603.50$ \\
\hline \$Change & & $\$ 460.20$ & $\$ 529.50$ & $\$ 1,263.60$ & $\$ 675.60$ & $\$ 777.00$ & $\$ 893.70$ \\
\hline \%Change & & $4.0 \%$ & $-6.3 \%$ & $8.4 \%$ & $4.2 \%$ & $4.6 \%$ & $5.0 \%$ \\
\hline Housing/Dining & $\$ 8,750.00$ & $\$ 9,000.00$ & $\$ 9,360.00$ & $\$ 9,360.00$ & $\$ 9,360.00$ & $\$ 9,360.00$ & $\$ 9,360.00$ \\
\hline \%Change & & $29 \%$ & $4.0 \%$ & $0.0 \%$ & $0.0 \%$ & $0.0 \%$ & $0.0 \%$ \\
\hline
\end{tabular}




\section{ENROLLMENT PLANNING}

Planned Growth by Student Type (for E\&G students at all campuses)

\begin{tabular}{|c|c|c|c|c|c|c|c|c|c|}
\hline $\begin{array}{l} \\
\text { UNDERGRADUATE }\end{array}$ & $\begin{array}{l}5 \text { YEAR } \\
\text { TREND } \\
\text { (2005-06 to } \\
2010-11) \\
\end{array}$ & \multicolumn{2}{|c|}{$\begin{array}{c}2010-11 \\
\text { ACTUAL } \\
\text { HEADCOUNT }\end{array}$} & \multicolumn{2}{|c|}{$\begin{array}{c}2012-13 \\
\text { PLANNED } \\
\text { HEADCOUNT }\end{array}$} & \multicolumn{2}{|c|}{$\begin{array}{c}\text { 2013-14 } \\
\text { PLANNED } \\
\text { HEADCOUNT }\end{array}$} & \multicolumn{2}{|c|}{$\begin{array}{c}3 \text { YEAR } \\
\text { (2014-15) } \\
\text { PLANNED } \\
\text { HEADCOUNT }\end{array}$} \\
\hline FTIC (Regular Admit) & $1 \%$ & 16,226 & $54 \%$ & 16,000 & $52 \%$ & 15,600 & $52 \%$ & 15,100 & $51 \%$ \\
\hline FTIC (Profile Admit) & $-60 \%$ & 218 & $1 \%$ & 200 & $1 \%$ & 200 & $1 \%$ & 200 & $1 \%$ \\
\hline AA Transfers* & $31 \%$ & 9,518 & $30 \%$ & 9,125 & $29 \%$ & 8,725 & $29 \%$ & 8,550 & $29 \%$ \\
\hline Other Transfers & $-2 \%$ & 5,363 & $17 \%$ & 5,575 & $18 \%$ & 5,375 & $18 \%$ & 5,500 & $19 \%$ \\
\hline Subtotal & $6 \%$ & 31,325 & $100 \%$ & 30,900 & $100 \%$ & 29,900 & $100 \%$ & 29,350 & $100 \%$ \\
\hline \multicolumn{10}{|l|}{ GRADUATE STUDENTS } \\
\hline Master's & $20 \%$ & 5,935 & $67 \%$ & 6,050 & $67 \%$ & 6,200 & $68 \%$ & 6,350 & $68 \%$ \\
\hline Research Doctoral & $23 \%$ & 2,289 & $26 \%$ & 2,312 & $26 \%$ & 2,335 & $25 \%$ & 2,358 & $25 \%$ \\
\hline Professional Doctoral & $24 \%$ & 604 & $7 \%$ & 624 & $7 \%$ & 644 & $7 \%$ & 664 & $7 \%$ \\
\hline Subtotal & $21 \%$ & 8,828 & $100 \%$ & 8,986 & $100 \%$ & 9,179 & $100 \%$ & 9,372 & $100 \%$ \\
\hline NOT-DEGREE SEEKING & $-5 \%$ & 1,693 & & 1,524 & & 1,650 & & 1,800 & \\
\hline MEDICAL & $\% \Delta$ & 473 & & 480 & & 480 & & 480 & \\
\hline TOTAL & $\% \Delta$ & 42,319 & & 41,890 & & 41,209 & & 41,002 & \\
\hline
\end{tabular}

Note*: AA transfers refer only to transfers from the Florida College System.

Planned Growth by Method of Instruction (for E\&G students at all campuses)

\begin{tabular}{|c|c|c|c|c|c|c|c|c|c|}
\hline & \multirow{2}{*}{$\begin{array}{c}5 \text { YEAR } \\
\text { TREND } \\
\text { (2005-06 to } \\
2010-11) \\
\end{array}$} & \multicolumn{2}{|c|}{ 2010-11 } & \multicolumn{2}{|c|}{$2012-13$} & \multicolumn{2}{|c|}{ 2013-14 } & \multicolumn{2}{|c|}{$\begin{array}{c}3 \text { YEAR } \\
\text { (2014-15) }\end{array}$} \\
\hline & & $\begin{array}{c}\text { ACTUAL } \\
\text { FTE }\end{array}$ & $\begin{array}{c}\% \text { of } \\
\text { TOTAL }\end{array}$ & $\begin{array}{c}\text { PLANNED } \\
\text { FTE }\end{array}$ & $\begin{array}{c}\% \text { of } \\
\text { TOTAL }\end{array}$ & $\begin{array}{c}\text { PLANNED } \\
\text { FTE }\end{array}$ & $\begin{array}{c}\% \text { of } \\
\text { TOTAL }\end{array}$ & $\begin{array}{c}\text { PLANNED } \\
\text { FTE }\end{array}$ & $\begin{array}{c}\% \text { of } \\
\text { TOTAL }\end{array}$ \\
\hline \multicolumn{10}{|l|}{ UNDERGRADUATE } \\
\hline DISTANC & $17 \%$ & 3,555 & $18 \%$ & 3733 & $18 \%$ & 3920 & $18 \%$ & 4116 & $18 \%$ \\
\hline HYBRID (50\%-79\%) & $0 \%$ & 322 & $2 \%$ & 338 & $2 \%$ & 355 & $2 \%$ & 373 & $2 \%$ \\
\hline TRADITIONAL (<50\%) & $83 \%$ & 16260 & $81 \%$ & 17073 & $81 \%$ & 17927 & $81 \%$ & 18823 & $81 \%$ \\
\hline TOTAL & $100 \%$ & 20,137 & $100 \%$ & 21,144 & $100 \%$ & 22,201 & $100 \%$ & 23,312 & $100 \%$ \\
\hline \multicolumn{10}{|l|}{ GRADUATE } \\
\hline DISTANCE (80\%) & $19 \%$ & 980 & $19 \%$ & 1029 & $19 \%$ & 1080 & $19 \%$ & 1134 & $19 \%$ \\
\hline HYBRID (50\%-79\%) & $0 \%$ & 107 & $2 \%$ & 112 & $2 \%$ & 118 & $2 \%$ & 124 & $2 \%$ \\
\hline TRADITIONAL (<50\%) & $81 \%$ & 4016 & $79 \%$ & 4217 & $79 \%$ & 4428 & $79 \%$ & 4649 & $79 \%$ \\
\hline TOTAL & $100 \%$ & 5,102 & $100 \%$ & 5,358 & $100 \%$ & 5,626 & $100 \%$ & 5,907 & $100 \%$ \\
\hline
\end{tabular}

Note: Full-time Equivalent (FTE) student is a measure of instructional effort (and student activity) that is based on the number of credit hours that students enroll. FTE is based on the Florida definition, which divides undergraduate credit hours by 40 and graduate credit hours by 32 . Distance Learning is a course in which at least 80 percent of the direct instruction of the course is delivered using some form of technology when the student and instructor are separated by time or space, or both (per 1009.24(17), F.S.). Hybrid is a course where $50 \%$ to $79 \%$ of the instruction is delivered using some form of technology, when the student and instructor are separated by time or space, or both (per SUDS data element 2052). Traditional (and Technology Enhanced) refers to primarily face to face instruction utilizing some form of technology for delivery of supplemental course materials for no more than $49 \%$ of instruction (per SUDS data element 2052). 


\section{ENROLLMENT PLANNING (continued)}

Statutorily Required Enrollment Plan (Based on State-Fundable Florida FTE)

\begin{tabular}{|c|c|c|c|c|c|c|c|c|}
\hline & $\begin{array}{l}\text { Funded } \\
2011-12\end{array}$ & $\begin{array}{c}\text { Estimated } \\
2011-12\end{array}$ & $\begin{array}{l}\text { Funded } \\
2012-13\end{array}$ & $\begin{array}{c}\text { Planned } \\
2012-13\end{array}$ & $\begin{array}{l}\text { Planned } \\
\text { 2013-14 }\end{array}$ & $\begin{array}{l}3 \text { Year } \\
\text { Planned } \\
2014-15\end{array}$ & $\begin{array}{c}5 \text { Year } \\
\text { Planned } \\
2016-17\end{array}$ & $\begin{array}{c}\text { 5-Year } \\
\text { Projected } \\
\text { Average } \\
\text { Annual } \\
\text { Growth } \\
\text { Rate }\end{array}$ \\
\hline \multicolumn{9}{|l|}{ Florida Resident } \\
\hline LOWER DIVISION & 8617 & 7763 & 8617 & 7651 & 7592 & 7586 & 7747 & $0.3 \%$ \\
\hline UPPER DIVISION & 9999 & 10070 & 9999 & 10662 & 10416 & 10244 & 10351 & $-0.74 \%$ \\
\hline GRAD I & 2672 & 2211 & 2672 & 2212 & 2179 & 2166 & 2216 & $0.05 \%$ \\
\hline GRAD ॥ & 623 & 807 & 623 & 751 & 763 & 778 & 821 & $2 \%$ \\
\hline TOTAL & 21911 & 20851 & 21911 & 20,522 & 20,512 & 20,609 & 21,135 & $-0.17 \%$ \\
\hline \multicolumn{9}{|c|}{ Not a Florida Resident } \\
\hline LOWER DIVISION & 0 & 349 & 0 & 522 & 606 & 709 & 995 & $17 \%$ \\
\hline UPPER DIVISION & 0 & 344 & 0 & 452 & 491 & 537 & 647 & $10 \%$ \\
\hline GRAD I & 0 & 310 & 0 & 410 & 440 & 473 & 547 & $8 \%$ \\
\hline GRAD II & 0 & 437 & 0 & 519 & 545 & 572 & 630 & $5 \%$ \\
\hline TOTAL & 1302 & 1439 & 1302 & 1902 & 2082 & 2291 & 2820 & $11 \%$ \\
\hline \multicolumn{9}{|l|}{ Total } \\
\hline LOWER DIVISION & 8617 & 8112 & 8617 & 8173 & 8198 & 8295 & 8742 & $2 \%$ \\
\hline UPPER DIVISION & 9999 & 10414 & 9999 & 11114 & 10907 & 10781 & 10998 & $-0.3 \%$ \\
\hline GRAD I & 2672 & 2521 & 2672 & 2621 & 2620 & 2639 & 2763 & $1 \%$ \\
\hline GRAD II & 623 & 1244 & 623 & 1270 & 1307 & 1350 & 1452 & $3 \%$ \\
\hline TOTAL & 23,213 & 22,290 & 23,213 & 23,179 & 23,031 & 23,065 & 23,955 & $1 \%$ \\
\hline $\begin{array}{l}\text { TOTAL } \\
\text { (US FTE) }\end{array}$ & 30,950 & 29,720 & 30,950 & 30,897 & 30,701 & 30,745 & 31,932 & $\%$ \\
\hline
\end{tabular}

Note: Full-time Equivalent (FTE) student is a measure of instructional effort (and student activity) that is based on the number of credit hours that students enroll. FTE is based on the Florida definition, which divides undergraduate credit hours by 40 and graduate credit hours by 32 .

Medical Student Headcounts (FTE does not apply)

\section{Medicine Headcounts}

\begin{tabular}{|lcccccccc|}
\hline FLORIDA RESIDENT & 480 & 445 & 480 & 436 & 432 & 432 & 432 & $-0.18 \%$ \\
\hline NON-RESIDENT & 0 & 32 & 0 & 44 & 48 & 48 & 48 & $1.76 \%$ \\
\hline TOTAL & $\mathbf{4 8 0}$ & $\mathbf{4 7 7}$ & $\mathbf{4 8 0}$ & $\mathbf{4 8 0}$ & $\mathbf{4 8 0}$ & $\mathbf{4 8 0}$ & $\mathbf{4 8 0}$ & $\mathbf{0 . 0 0 \%}$
\end{tabular}




\section{ACADEMIC PROGRAM COORDINATION}

New Programs To Be Considered by University in 2012-13 for Implementation

\begin{tabular}{|c|c|c|c|c|c|c|}
\hline PROGRAM TITLES & $\begin{array}{c}\text { CIP CODE } \\
\text { 6-digit } \\
\end{array}$ & $\begin{array}{c}\text { AREA } \\
\text { OF STRATEGIC } \\
\text { EMPHASIS } \\
\end{array}$ & $\begin{array}{l}\text { OTHER } \\
\text { UNIVERSITIES } \\
\text { WITH SAME } \\
\text { PROGRAM } \\
\end{array}$ & $\begin{array}{l}\text { OFFERED VIA } \\
\text { DISTANCE } \\
\text { LEARNING } \\
\text { IN SYSTEM } \\
\end{array}$ & $\begin{array}{l}\text { PROJECTED } \\
\text { ENROLLMENT } \\
\text { in 5th year } \\
\end{array}$ & $\begin{array}{l}\text { PROPOSED DATE } \\
\text { OF SUBMISSION } \\
\text { TO UBOT }\end{array}$ \\
\hline R'S PROGRAM & & & & & & \\
\hline $\begin{array}{l}\text { B.A. Film and New Media } \\
\text { Studies (Tampa) }\end{array}$ & 50.0602 & No & $\begin{array}{c}\text { FSU,UF,UNF,UWF,UCF, } \\
\text { FIU,FAU }\end{array}$ & & 117 & May 2013 \\
\hline
\end{tabular}

*Program has not completed internal approval process

${ }^{\star}$ Substitution for B.S. Digital Design \& Tech.

\section{MASTER'S, SPECIALIST AND OTHER ADVANCED MASTER'S PROGRAMS}

\begin{tabular}{lcccccc}
\hline Sports \& Entertainment Mgt (Tampa) & 31.0504 & No & $\begin{array}{c}\text { FAMU,FAU,FIU,FSU, } \\
\text { UCF,UF }\end{array}$ & N & 25 & May 2013 \\
\hline Athletic Training (Tampa) & 51.0913 & No & FIU & N & 30 & May 2013 \\
\hline Metabolic \& Nutritional Medicine (Tampa) & 26.9999 & STEM & None & N/Y & 37.5 & May 2013
\end{tabular}

*Program has not completed internal review process

New Programs To Be Considered by University in 2013-15 for Implementation

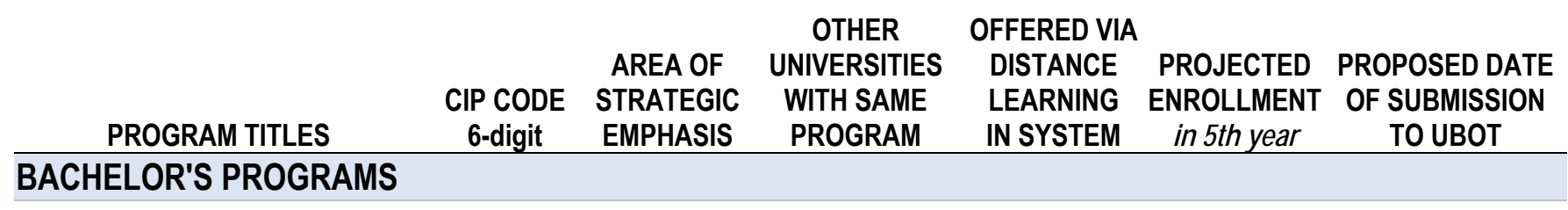

\section{MASTER'S, SPECIALIST AND OTHER ADVANCED MASTER'S PROGRAMS}

\begin{tabular}{lcccccc}
\hline Diplomacy and Strategic Studies & 30.2011 & No & FIU & Partial & 35 & August 2015 \\
\hline Physician Assistant & 51.0912 & STEM & UF & N & 50 & August 2014 \\
\hline DOCTORAL PROGRAMS & & & & & & \\
\hline Cell and Molecular Biology & 26.0400 & STEM & UF & N & 40 & August 2014 \\
\hline Integrative Biology & 26.1399 & STEM & UF, UCF & N & 40 & August 2014 \\
\hline Rehabilitation Sciences & 51.2314 & STEM & UF & Partial & 20 & August 2015 \\
\hline Translational Neurosciences & 26.0608 & STEM & None & Partial & 20 & August 2015
\end{tabular}




\section{KEY PERFORMANCE INDICATOR DEFINITIONS}

\section{Goals Common to All Universities \\ Academic Quality \\ National Ranking for University and Program(s)}

\section{Avg. SAT Score}

\section{Avg. HS GPA (on 4.0 scale)}

\section{Professional/Licensure Exam \\ First-time Pass Rates}

Exams Above National/State Benchmark

Exams Below National/State Benchmark

\section{Percent of Undergraduate Seniors Participating in a Research Course}

\section{Operational Efficiency}

Freshman Retention Rate

\section{FTIC Graduation Rates \\ In 4 years (or less) \\ In 6 years (or less)}

\author{
AA Transfer Graduation Rates \\ In 2 years (or less) \\ In 4 years (or less)
}

Describe plans for increasing national preeminence of University and select programs.

The average SAT score for all three subtests (reading, mathematics and writing) for Admitted and Registered FTIC (B,E) students.

The average HS GPA for Admitted and Registered FTIC (B,E) students.

The number of exams with first-time pass rates above and below the national or state average, as reported in the 2010-11 Accountability report, including: Nursing, Law, Medicine (3 subtests), Veterinary, Pharmacy, Dental (2 subtests), Physical Therapy, and Occupational Therapy.

This metric represents the percentage of seniors who enrolled in a Research course during their last year. Board staff will work with University officials during the summer of 2012 to determine a system-wide definition of 'a research course'.

The percentage of a full-time, first-time-in-college (FTIC) undergraduate cohort (entering in fall term or summer continuing to fall) that is still enrolled or has graduated from the same institution in the following fall term.

First-time-in-college (FTIC) cohort is defined as undergraduates entering in fall term (or summer continuing to fall) with fewer than 12 hours earned since high school graduation. The rate is the percentage of the initial cohort that has either graduated or is still enrolled in the fourth or sixth academic year. Both full-time and parttime students are used in the calculation. Note: Students of degree programs longer than four years are included in the cohorts. The initial cohort is revised to remove students, who have allowable exclusions as defined by IPEDS, from the cohort. Students with unreported gender are included.

AA Transfer cohort is defined as undergraduates entering in the fall term (or summer continuing to fall) and having earned an AA degree from an institution in the Florida College System. The rate is the percentage of the initial cohort that has either graduated or is still enrolled in the second or fourth academic year. Both full-time and part-time students are used in the calculation. Note: Students of degree programs longer than four years are included in the cohorts. The initial cohort is revised to remove students, who have allowable exclusions as defined by IPEDS, from the cohort.

The percentage of baccalaureate degrees awarded within $110 \%$ of the hours required for a degree. Excluding students with dual majors, this metric computes total academic credit as a percentage of catalog hours required for the students major (excluding remedial coursework). For the purposes of calculating excess hours, remedial credit hours includes up to 10 foreign language credit hours that are excluded for transfer students in Florida. 


\section{Return on Investment}

Bachelor's Degrees Awarded

Percent of Bachelor's Degrees in STEM

Graduate Degrees Awarded

Percent of Graduate Degrees in STEM

Percent of Baccalaureate Graduates Employed in Florida

Percent of Baccalaureate Graduates
Continuing their Education (in FL)

Annual Gifts Received (\$M)

Endowment (\$M)

Goals Specific to Research Universities

Academic Quality

Faculty Awards

National Academy Members

Number of Post-Doctoral appointees
This is a count of baccalaureate degrees granted. Students who earn two distinct degrees in the same term are counted twice whether their degrees are from the same six-digit CIP code or different CIP codes. Students who earn only one degree are counted once - even if they completed multiple majors or tracks. The percentage of baccalaureate degrees that are classified as STEM by the Board of Governors in the SUS program inventory.

This is a count of graduate degrees granted.

The percentage of graduate degrees that are classified as STEM by the Board of Governors in the SUS program inventory.

This is the percentage of baccalaureate graduates with valid social security numbers that are employed in Florida during the Oct-Dec fiscal quarter based on FETPIP data.

This is the percentage of baccalaureate graduates with valid social security numbers that are continuing their education in Florida during the Oct-Dec fiscal quarter based on FETPIP data.

As reported in the Council for Aid to Education's Voluntary Support of Education (VSE) survey in the section entitled "Gift Income Summary," this is the sum of the present value of all gifts (including outright and deferred gifts) received for any purpose and from all sources during the fiscal year, excluding pledges and bequests. (There's a deferred gift calculator at www.cae.org/vse.) The present value of non-cash gifts is defined as the tax deduction to the donor as allowed by the IRS.

Endowment value at the end of the fiscal year, as reported in the annual NACUBO Endowment Study (changed to the NACUBOCommon Fund Study of Endowments in 2009).

Awards include: American Council of Learned Societies (ACLS) Fellows, Beckman Young Investigators, Burroughs Wellcome Fund Career Awards, Cottrell Scholars, Fulbright American Scholars, Getty Scholars in Residence, Guggenheim Fellows, Howard Hughes Medical Institute Investigators, Lasker Medical Research Awards, MacArthur Foundation Fellows, Andrew W. Mellon Foundation Distinguished Achievement Awards, National Endowment for the Humanities (NEH) Fellows, National Humanities Center Fellows, National Institutes of Health (NIH) MERIT, National Medal of Science and National Medal of Technology, NSF CAREER awards (excluding those who are also PECASE winners), Newberry Library Long-term Fellows, Pew Scholars in Biomedicine, Presidential Early Career Awards for Scientists and Engineers (PECASE), Robert Wood Johnson Policy Fellows, Searle Scholars, Sloan Research Fellows, Woodrow Wilson Fellows. As reported by the Top American Research Universities - see link. The number of National Academy members included in the National Academy of Sciences, National Academy of Engineering, and the Institute of Medicine.

As submitted to the National Science Foundation Survey of Graduate Students and Postdoctorates in Science \& Engineering (also known as the GSS). 


\section{Number of Science \& Engineering Disciplines nationally ranked in Top 100 for research expenditures}

\section{Return on Investment}

Total Research Expenditures (\$M)

Percent of R\&D Expenditures funded from External Sources

Patents Issued

Licenses/Options Executed

Licensing Income Received (\$M)

Number of Start-up Companies

Science \& Engineering Research Expenditures in non-medical/health sciences

National rank is higher than predicted by Financial Resources Ranking based on US News \& World Report

Research Doctoral Degrees Awarded

Professional Doctoral Degrees Awarded
The number of Science \& Engineering disciplines the university ranks in the top 100 (for public and private universities) based on the National Science Foundation's annual survey for R\&D expenditures, which identifies 8 broad disciplines within Science \& Engineering (Computer Science, Engineering, Environmental Science, Life Science, Mathematical Sciences, Physical Sciences, Psychology, and Social Sciences).

Total expenditures for all research activities (including non-science and engineering activities) as reported on the NSF annual survey. The percentage of total R\&D expenditures that come from Federal, Private Industry and Other sources (does not include State or Institutional funds).

The number of patents issued in the fiscal year as reported to AUTM.

Licenses/options executed in the fiscal year for all technologies as reported annually to the AUTM Licensing Survey. Each agreement is counted separately.

License issue fees, payments under options, annual minimums, running royalties, termination payments, amount of equity received when cashed-in, and software and biological material end-user license fees of $\$ 1,000$ or more, but not research funding, patent expense reimbursement, valuation of equity not cashed-in, software and biological material end-user license fees of less than $\$ 1,000$, or trademark licensing royalties from university insignia. The number of start-up companies that were dependent upon the licensing of University technology for initiation as reported in the AUTM Licensing Survey.

This metric reports the Science \& Engineering total R\&D expenditures minus the research expenditures for medical sciences as reported by the National Science Foundation (see link, table 36 minus table 52).

This metric compares the overall national university ranking to the financial resources rank as reported by the US News and World report.

The number of research doctoral degrees awarded annually.

The number of professional doctoral degrees awarded annually. 